\title{
Syzygium myrtifolium Walp. flowering stages and its visitor insects
}

\author{
DEDEN MUDIANA ${ }^{*}$, ESTI E. ARIYANTI"v \\ Purwodadi Botanic Garden, Research Center of Plant Conservation and Botanical Gardens, Indonesian Institute of Sciences. \\ J1. Raya Surabaya-Malang Km 65, Purwodadi, Pasuruan 67163, East Java, Indonesia. "email: dmudiana@yahoo.com, ^»estimudiana@yahoo.com
}

Manuscript received: 7 July 2021. Revision accepted: 27 July 2021.

\begin{abstract}
Mudiana D, Ariyanti EE. 2021. Syzygium myrtifolium Walp. flowering stages and its visitor insects. Biodiversitas 22: $3489-$ 3496. "Pucuk merah" or Red lip (Syzygium myrtifolium Walp.) is widely known as an ornamental plant used as garden components. This species belongs to the Myrtaceae family with the scientific name Syzygium myrtifolium Walp. This paper specifically aimed to observe the stages of flowering and visiting insects of $S$. myrtifolium, while the determination of insects as pollinators was not carried out in this study, and was intended merely to make a species list of visiting insects, without counting the number of individuals and the times of their visits. These are done by examining two individual trees of S. myrtifolium (which have flowered and fruited several times) during its flowering season, recording all visible flower developments and the visitor insects. The visitor insects were observed during flower bloom. The results showed ten stages of flowering process in S. myrtifolium starting from emerging flower buds until fruits riped, which took 105-124 days. Twelve species of insects were recorded visiting flowers of S. myrtifolium during full blooming period, namely Euploea core, Hypolimnas bolina, Telicota colon, Eurema hecabe, Rapala pheretima, Apis cerana, Apis mellifera, Trigona sp., Dysphania sagana, Amata trigonophora, Chrysomya megacephala, Lucilia caesar. They belong to three orders, i.e. Diptera, Hymenoptera and Lepidoptera; and eight families, namely Calliphoridae, Apidae, Hesperiidae, Nymphalidae, Lycaenidae, Geometridae, Erebidae, and Pieridae.
\end{abstract}

Keywords: Flowering stages, pollinators, pucuk merah, Syzygium myrtifolium

\section{INTRODUCTION}

The genus Syzygium Gaertn. is considered to be one of the largest genera of flowering plants. This genus has a fairly wide distribution covering tropical and subtropical regions including South Africa, South America, Southeast Asia and Australia (Badou et al. 2020), whereas S. myrtifolium is native to Bangladesh, Borneo, Jawa, Malaya, Myanmar, Philippines, Sumatera, Thailand (POWO 2019).

Syzygium myrtifolium Walp. which is known as "pucuk merah" or red lip, kelat oil, is a species of the Myrtaceae family that is widely recognized as an ornamental plant. It has several synonyms, i.e.: Eugenia oleina Wight, Eugenia parva C.B.Rob., Eugenia sinubanensis Elmer, Syzygium campanellum Miq., Syzygium campanulatum Korth., Syzygium campanulatum var. longistylum Chantar. \& J.Parn., Syzygium sinubanense (Elmer) Diels (POWO 2019). Generally, the Syzygium genus is used and known as a fruit-producing plant, medicinal raw material and essential oil plant. As fruit-producing plants, several Syzygium species are widely known such as wax apple or jambu Semarang (Syzygium samarangense), water apple or jambu air (Syzygium aqueum), kopo or kupa (Syzygium polycephalum) and Malay apple or jambu darsono/jambu bol (Syzygium malaccense); meanwhile, as a producer of medicinal raw materials and essential oils which are commonly known, such as cloves (Syzygium aromaticum), bay or salam leaves (Syzygium polyanthum), and java pulm or juwet/jamblang (Syzygium cumini). For use as an ornamental plant, the presence of "pucuk merah" (Syzygium myrtifolium) is an interesting phenomenon. Its presence and widespread use show that the community accepts this species to meet the needs of ornamental plants. Efendi et al. (2017) stated that in Cibodas Botanical Garden, this species was introduced to the community as an ornamental plant in environmental education activities for botanical garden visitors. At present, this species is used in many places as a component in gardens and roadside plants (Agus et al. 2015). Some of the things that might cause this were: an attractive red color on young leaves, the size of the plant habit (short shrubs) therefore it was easy to prune and arrange, easy to propagate and provide seeds, and adaptive in various habitat conditions, moreover it has abundant flowers. This condition inadvertently also provides ecosystem services for pollinating insects that visit their flowers. These pollinating insects are very important for the survival of plants and will ultimately be useful for human life.

Therefore, information about the insect pollinator Syzygium myrtifolium is expected to be useful for the sustainable use of this plant. However, research on its pollinators and flowering development has never been done before. Most of the research on this species had been carried out regarding its potential as traditional medicine, including antimutagenic effect activities (Lingga et al. 2018), antioxidants (Santoni et al. 2013, Purnomo and Yuliati 2020, Anggraini 2017), antidiabetic (Hasti et al. 2016), burn medication (Indriani et al. 2020), antibacterial (Haryati et al. 2015), anti-hyperuricemia (Juwita et al. 2017), potential as a natural hand sanitizer (Putri et al. 2020), and potential for food coloring agents (Syahri 2012). 
Meanwhile, Sulistyo (2017) examined this species as a noise reduction in horticultural plant systems.

Utilization of $S$. myrtifolium which is quite extensive as an ornamental plant and its potential to provide ecosystem services as a source of insect food can help maintain a mutually beneficial relationship between pollinators and plants. To support this, it is necessary to know the character of the S. myrtifolium flower and the species of pollinators. This paper specifically aimed to observe the stages of flowering and visiting insects of $S$. myrtifolium, while the determination of insects as pollinators was not carried out in this study.

\section{MATERIALS AND METHODS}

\section{Study area}

The research was conducted in May-June 2019 and March 2020 which coincided with the flowering season of S. myrtifolium. Two individual trees which were about 3 meters high and $1 \mathrm{~m}$ wide canopy and have flowered and fruited several times, were observed. The research location was in Lawang, Malang District, East Java, Indonesia. The used equipment included a camera to take pictures/photos of flowers and visitor insects; stationery, and the $S$. myrtifolium tree, which has been regularly flowering.

\section{Procedures}

Observation of the morphology of flowers is carried out by observing, measuring and documenting the morphological characters of flowers. Flowering stages were observed started from the appearance of flower buds until the fruits were all ripe. Each change in flowering stage was documented and the duration of each stage was recorded. The flower samples were taken during the blooming phase, then the morphological characters were observed and recorded. The inflorescence that has the most complete condition (not falling) and can represent the overall characters of the inflorescence was taken and observed. The observed morphological characters of the flowers were i.e.: the number of flowers per inflorescence, the length of the pedicel (flower stalk), the number and the size of tepals (modification from Dewi et al. 2015), tepal color, stamen number and size, pistil number and size, fruit size and shape, seed number and size. The plant habit and the type of inflorescence were also examined.

Observations of insect visitors to the $S$. myrtifolium flower were carried out during the full blooming period. Observations were made in the morning at around 08.00$11.00 \mathrm{am}$, which was the time when the most insects visited. Photo documentation was carried out mainly for each different insect that visits the flower. This was intended merely to make a list of the insect species that visited flowers, without counting the number of individuals and the times of their visits. Each different species of insect that visited the flower was photographed and recorded and then the species was identified using various literature sources by comparing the images taken to the mixture of documentation, identification key and insect photos from literature.

\section{RESULTS AND DISCUSSION}

\section{Morphological characters}

Syzygium myrtifolium is a shrub or small tree, leaves narrowly lanceolate to ovate-lanceolate, base narrowed into petiole, apex acuminate, young leaves are red later turn into reddish-green then green. Flower perianths were white and indistinguishable between the sepals and the petals so they were called tepals, forming a calyptra with $2 \mathrm{~mm}$ wide, slightly flat in shape. In this study, all observed morphological characters were shown in Table 1, while the appearance of habit, flowers, inflorescence diagrams, fruit, and seeds was shown in Figure 1. These morphological characters are features of $S$. myrtifolium which are easy to observe and recognize in the field, considering the small size of the flowers. One of the characters that can be used for identification is the flower.

\section{Flower development of $S$. myrtifolium}

As many as ten flowering stages of $S$. myrtifolium were noted and presented in Table 2.

\section{Visitor insects of $S$. myrtifolium}

Twelve species of insects were recorded visiting flowers of $S$. myrtifolium during full blooming period, they were shown in Table 3 and Figure 2.

Table 1. The results of observations of the morphological characters of Syzygium myrtifolium.

\begin{tabular}{ll}
\hline Morphological character & Observation result \\
\hline & \\
Plant height & $0.75-3 \mathrm{~m}$ \\
Inflorescence type & panicle \\
Inflorescence length & $3.5-8 \mathrm{~cm}$ \\
Number of flowers on each inflorescence & $5-24$ \\
Pedicel length & $4 \mathrm{~mm}$ \\
The number tepal & 1 \\
Tepal color & white \\
Tepal size & $\pm 4 \mathrm{~mm}$ \\
The number of stamens & numerous \\
Stamen length & $4-5 \mathrm{~mm}$ \\
The number of pistils & 1 \\
Pistil length & $\pm 4 \mathrm{~mm}$ \\
Fruit shape & globose \\
Fruit diameter & $6-8 \mathrm{~mm}$ \\
The number of seeds & 1 \\
Seed diameter & $3-4 \mathrm{~mm}$ \\
Fruit color when young & green \\
Fruit color when ripe & dark purple to black \\
\hline
\end{tabular}




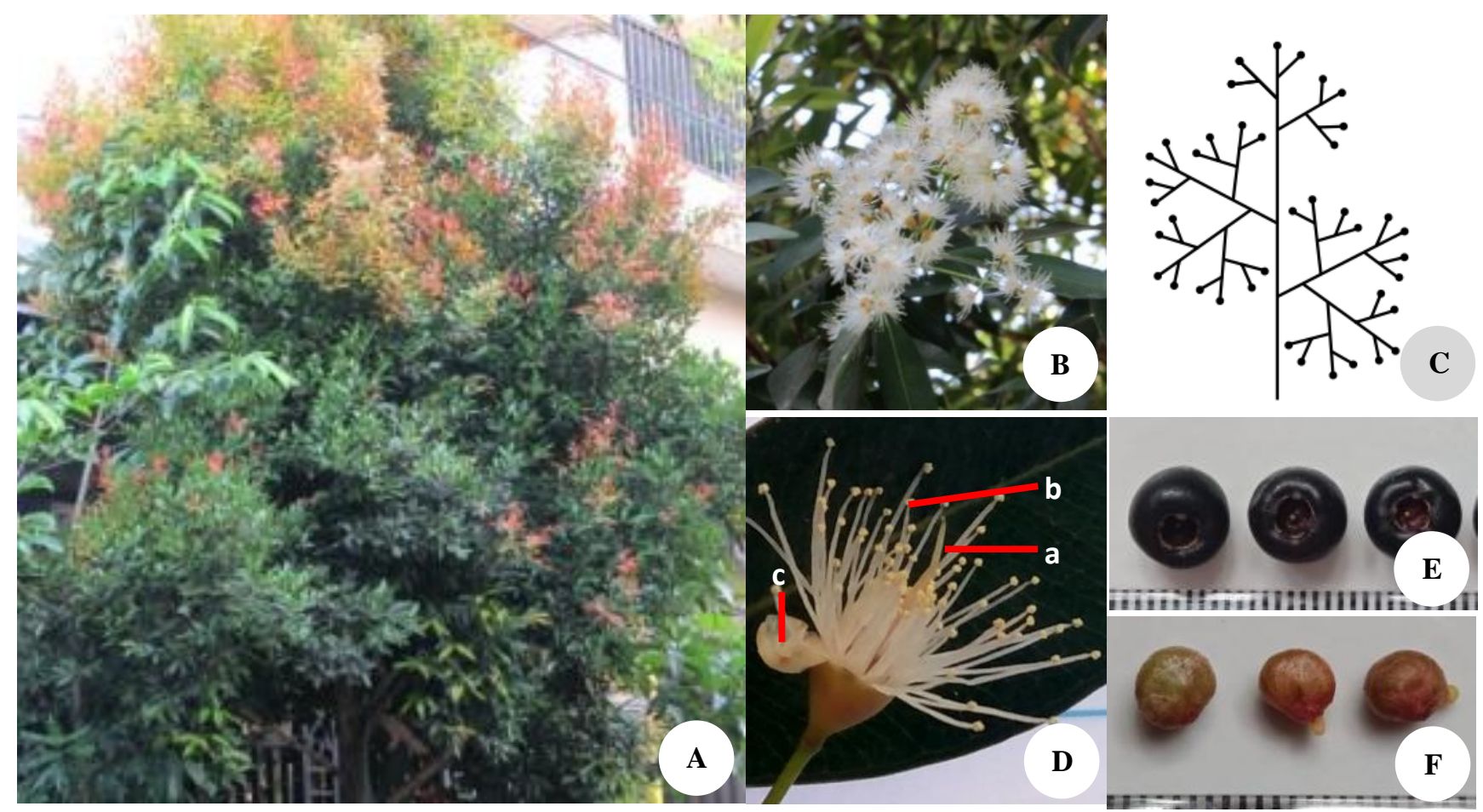

Figure 1. Morphology of Syzygium myrtifolium: A. Habit-a small tree with red young leaves, B. Inflorescence, C. Sketch of inflorescence type panicle (Endress 2010), D. Flower: a. Stamen, b. Pistil, c. Tepal, E. Fruits, F. Seeds

\section{Discussion}

The common name of $S$. myrtifolium in Indonesia is "pucuk merah" which means red shoots referred to the red young leaves (Figure 1.A). In general, the flower parts of $S$. myrtifolium consist of stamens, pistils, and tepals, as shown in Figure 1.D. Tepal is actually a flower perianth that cannot be distinguished between calyx and corolla (Meyer 2005). Therefore, the flower characters, namely inflorescence type, flower size, the color of the flowers and the shape of perianths, can be used to identify this species. In addition, the character of the fruit, especially the size, shape, color and number of seeds in the fruit are also character traits (Figure 1.E-F). The type of inflorescences on S. myrtifolium is panicle, which is an inflorescence in which the main peduncle is branched and the branches branch again; the whole often looks like a pyramid or cone shape (Figure 1.B-C). The sketch of inflorescence type was taken from Endress (2010) who worked on inflorescence morphology.

The flowering phase in S. myrtifolium as shown in Table 2, can be divided at least into 10 stages which lasted for 105-124 days, starting from the emergence of flower buds, extending peduncles, elongated inflorescences, enlarging flower buds, showy perianths, flowers started blooming, flowers perfectly blooming, enlarging ovules, fruit formation and fruit ripening. Stage 1 began with the emergence of potential flower buds on the twigs (no. 1). It took about 14 days to enter the second stage, when the stalk began to elongate and showed a second branching (no. 2). This second stage required 13 days roughly. The next stage was when the inflorescences were longer with more flower buds and the fourth branches were visible (no. 3). This third stage needed around 12 days until the fourth stage happened that was indicated by the enlargement of the flower buds and the peduncles stop elongating (no. 4). This stage took approximately 8 to 12 days. The fifth stage started when the perianths were showy and the flower buds had ovoid shape; this indicated the flower buds were about ready to bloom (no. 5). It took roughly 8 to 17 days. Subsequently, the stage at which several tepals opened, the stamens and pistils became visible, then the flowers started blooming (no. 6), was stage 6 which took 1-3 days. The next was stage 7 , marked by the full bloom of flowers, white in color, the stamens and pistils appearing together with the open tepals (no. 7). This stage took about 3 to 4 days. Stage 8 was marked by enlarging ovules, falling stamens and tepals off, and the basic shape of the flowers becoming visible (no. 8). It took around 16-18 days. Stage 9 was indicated by enlarging the flower base and starting to form fruits until young fruits had purplish-green in color as ripened (stage no. 9). This stage occupied 13-14 days. In the last stage, the fruits were completely ripe, black and had round-shape and were already contained seeds (no. $10)$; this process required 15-17 days. 
Table 2. The flowering stages of S. myrtifolium.

\begin{tabular}{cl}
$\begin{array}{c}\text { Stage } \\
\text { no. }\end{array}$ & Flowering stages \\
\hline 1 & Emerging buds: flower buds started to emerge \\
\hline 2 & $\begin{array}{l}\text { Extending peduncles: the peduncles started to extend until } \\
\text { showing a second branching }\end{array}$
\end{tabular}
more flower buds. Extension of the peduncle until the fourth branching was visible.

4 Enlarging flower buds: the peduncle was not growing longer along the flower buds were enlarged.

5 Showy perianths: the flower buds began to develop until they were perfectly ovoid in shape, which shows the perianths/tepals; flower buds were ready to bloom.

6 Flower started blooming: some of the flower buds have bloomed, marked by the opening of some tepals and the appearance of stamens and pistils.

7 Flower perfectly blooming: The flowers were perfectly blooming and completely open, white, the stamens and pistil appear simultaneously with the open tepals.

8 Enlarging ovules: tepals and stamens fell off, showing the flower's basic shape, which contained the ovule and pistil at the end part; ovules were started to enlarge.

9 Fruit formation: the base of the flowers was enlarge more, fruits were starting to form, young fruits had round shape, green, and gradually changed to purplish-green as they ripened.

Fruit ripening: The fruits were completely ripe, black and had round-shape and were already contained seeds.

Pictures of developmental stages

Duration (days)
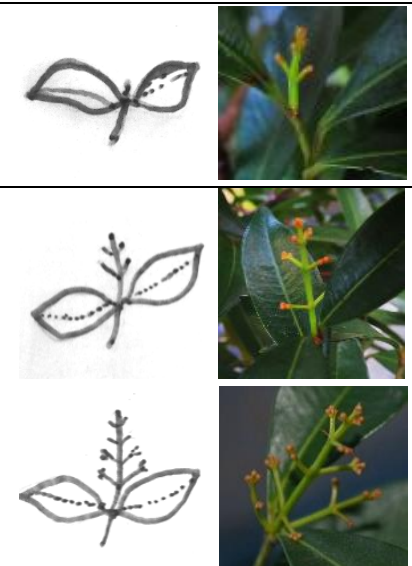

12
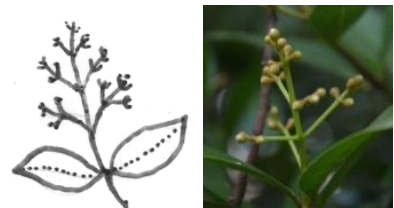

8-12
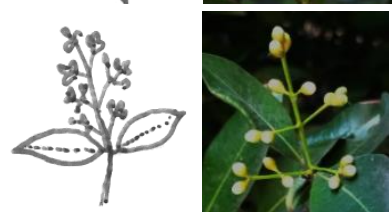

8-17
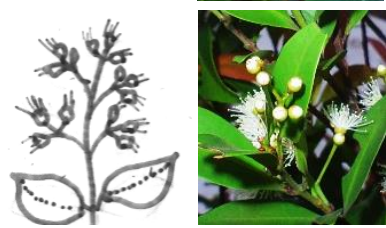

1-3

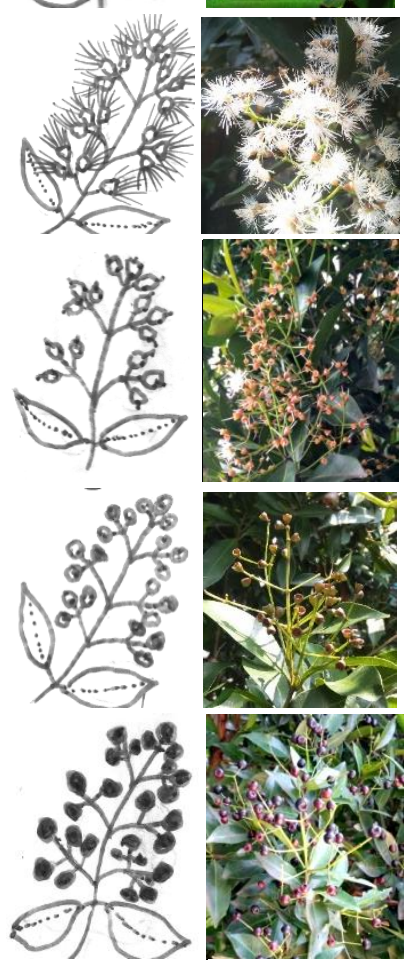


Table 3. Visitor insects of S. myrtifolium and their classification

\begin{tabular}{lllll}
\hline \multicolumn{1}{c}{ Order } & \multicolumn{1}{c}{ Family } & \multicolumn{1}{c}{ Genus } & \multicolumn{1}{c}{ Species } & \multicolumn{1}{c}{ Common name } \\
\hline Diptera & Calliphoridae & Chrysomya & Chrysomya megacephala & Oriental latrine fly \\
Diptera & Calliphoridae & Lucilia & Lucilia caesar & Blowfly \\
Hymenoptera & Apidae & Apis & Apis cerana & Eastern honey bee \\
Hymenoptera & Apidae & Apis & Apis mellifera & Western honey bee \\
Hymenoptera & Apidae & Trigona & Trigona sp. & Stingless bee \\
Lepidoptera & Hesperiidae & Telicota & Telicota colon & Common palm-dart butterfly \\
Lepidoptera & Nymphalidae & Euploea & Euploea core & Common crow butterfly \\
Lepidoptera & Nymphalidae & Hypolimnas & Hypolimnas bolina & Common egg fly butterfly \\
Lepidoptera & Lycaenidae & Rapala & Rapala pheretima & Copper flash butterfly \\
Lepidoptera & Pieridae & Eurema & Eurema hecabe & Common grass yellow butterfly \\
Lepidoptera & Geometridae & Dysphania & Dysphania sagana & Yellow tiger moth \\
Lepidoptera & Erebidae & Amata & Amata trigonophora & Tiger moth \\
\hline
\end{tabular}
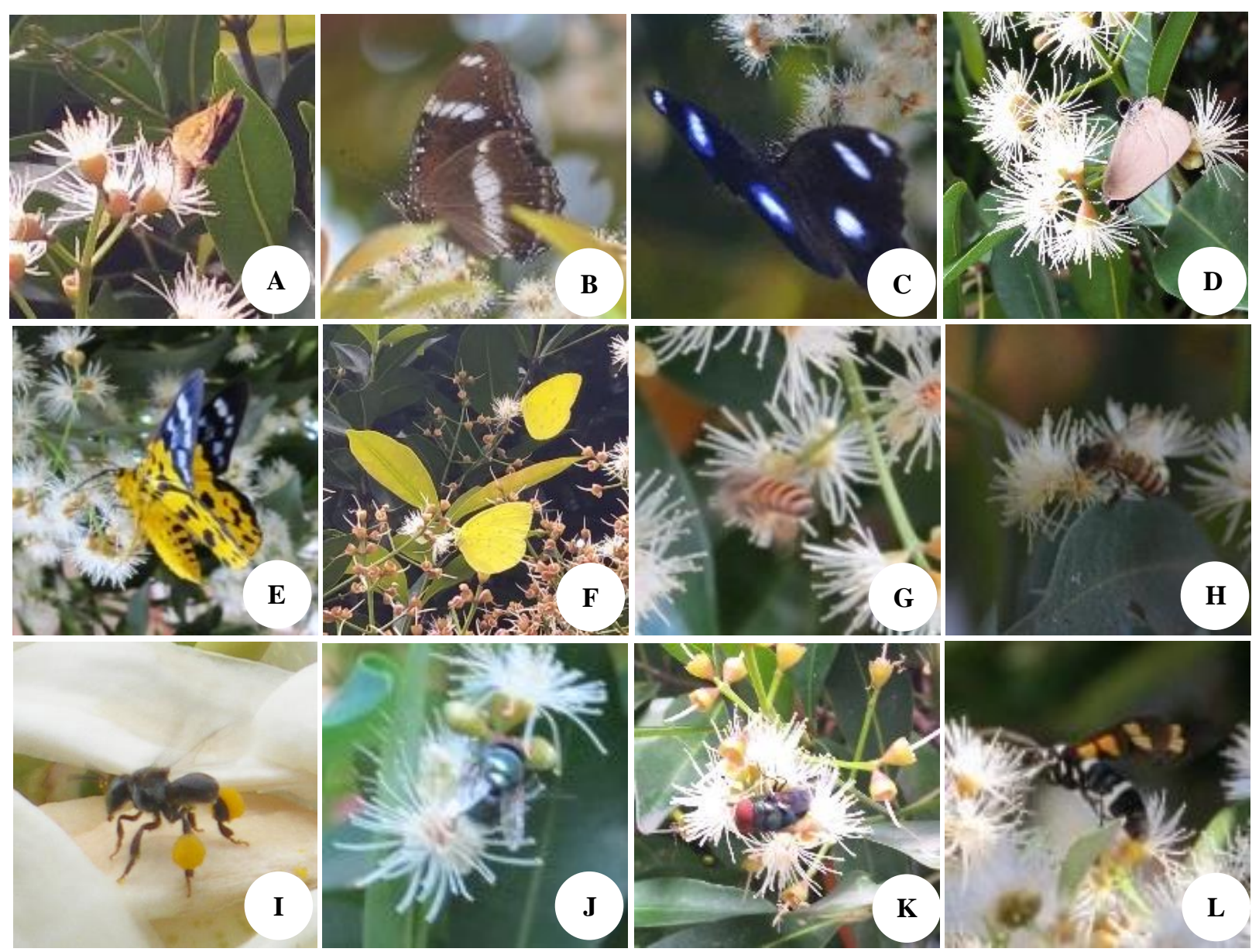

Figure 2. Visitor insects of S. myrtifolium: A. Telicota colon; B. Euploea core; C. Hypolimnas bolina; D. Rapala pheretima; E. Dysphania sagana; F. Eurema hecabe; G. Apis cerana; H. Apis mellifera; I. Trigona sp.; J. Lucilia caesar; K. Chrysomya megacephala; L. Amata trigonophora

The division of this flowering process into 10 stages was made based on the changes that appeared to occur gradually in the flowering process of S. myrtifolium during the observations in this study. However, in general, there are six stages of flowering process, namely: (i) evocation or flower induction, whereby events in a shoot meristem was altered in such a way as to produce flowers instead of leaves (Erwin 2005); (ii) flower initiation, was the formation of flower buds after induction (Erwin 2005); (iii) flower development was the process after flower initiation until anthesis (Erwin 2005); (iv) anthesis, which referred to the release of pollen by the stamen (Erwin 2005); (v) pollination and fertilization. Pollination is the process of transferring pollen to the stigma. Next will be followed by the fertilization process that occurs in the ovary; (vi) fruit development and seed formation. 


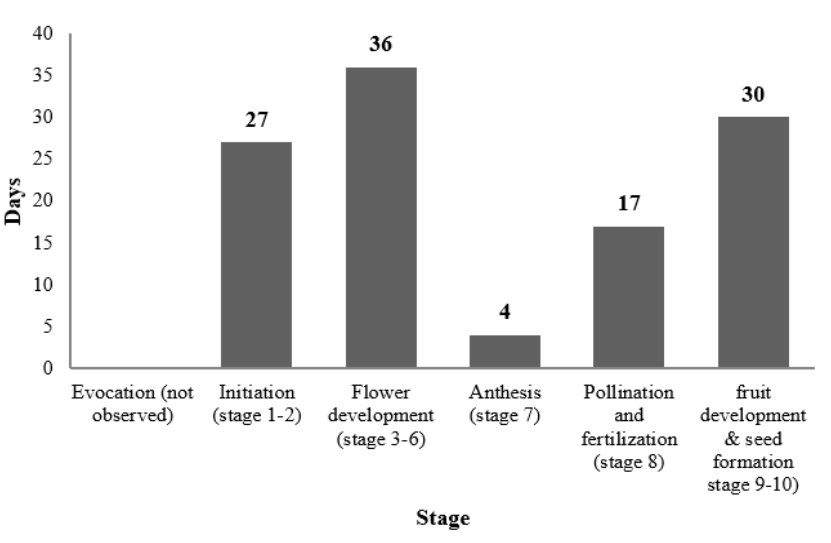

Figure 3. Average time (days) for each flowering stage observed in S. myrtifolium

Compared to these general stages, the ten stages of $S$. myrtifolium flowering process can be simplified into at least five stages. Figure 3 showed the average time on each stage of flowering process in S. myrtifolium which was simplified based on general flowering development. The first stage was evocation or flower induction, alas this stage was not observed in this study, so it could not be compared. The second stage was flower initiation, in this research showed stage 1 and stage 2, where took around 27 days. The flower development stage was the longest process and was represented by stage 3-6, which needed 36 days on average. Anthesis was denoted by stage 7 , was the shortest among the other processes and required only 4 days on average. Pollination and fertilization began at stage 8 , which needed more or less 17 days. The last process, fruit development and seed formation, was at stage 9-10, which took about 30 days.

One of the limitations of this study, the flower induction stage was not observed because the timing of this stage cannot be predicted with certainty. It should be observed months before flower buds appear. As Syamsuwida et al. (2012) observed flowering stages of Melia azedarach L., they discovered that the flowering induction occurred several months before flower buds appeared. Moreover, flower induction occurred in the cells, so it was necessary to observe by making microscopic preparations.

Several similar studies had been conducted on the same genus, namely $S$. pycnanthum (Mudiana and Ariyanti 2010), S. guineense subsp. macrocarpum (Badou et al. 2017), S. hirtum (Astuti et al. 2021), S. cumini (Bajpai et al. 2012), and S. caryophyllatum (Gethika and Sabu 2017). They showed different results, S. pycnanthum needed 8089 days to experience the whole process of flowering, S. guineense subsp. macrocarpum needed 116-128 days, whereas $S$. hirtum needed 95-105 days, S. cumini required 186-196 days and S. caryophyllatum needed 63-78 days. These differences can be explained by some opinions and research that has been done. In addition to different species (even though in the same genus), flowering is influenced by other factors that are quite complex. The pattern of flowering and all of its processes were considered of combination of all genetic, physiological and morphological characters of certain species. Flowering performance parameters among others consisted of the process of the emergence of the first flower buds, the process of the first flower appearing, the process until the appearance of $50 \%$ flowering, a continuous single flower period, etc; furthermore the factors of time, duration and frequency of flowering established the pattern of flowering (Jain 2011). Additionally, the flowering process is also influenced by external factors such as light, temperature, water, nutrients, microbes, pollinators, etc. (Cho et al. 2017).

The role of pollinators is important for this species since it is propagated one of which by seeds. To produce seeds, it is necessary to have a pollination process carried out by pollinators. Parnell (2003) suggested that most of the stamens in Myrtaceae (including Syzygium) had a dual function, namely as a pollen producer and as an attraction for pollinators to help spread and pollinate. Several studies had been conducted to study pollinators in Syzygium species, among others were Raju et al. (2014) which studied on S. alternifolium, Kuriakose et al. (2018) studied on $S$. occidentale, Hopper (1980) looked on $S$. tierneyanum, Boulter et al. (2005) observed on S. sayeri, Djonwangwe et al. (2011) looked on S. guineense var. guineense specifically, Tarwotjo et al. (2019) studied on $S$. aqueum Merah Delima, Hashifah and Lazuardi (2016) studied on visitor insects of $S$. samarangense, Geethika and Sabu (2017) examined pollination of S. caryophyllatum, Lack and Kevan (1984) studied on reproductive biology of S. syzygioides. Based on those previous researches, some of the known pollinators of Syzygium were not only insects but also included: possums, bats and birds. However, this study only looked at visiting insects specifically and it has not been confirmed as pollinators yet since not all flowervisiting insects are pollinators. This can be considered as the other limitation of this study. Boulter et al. (2006) and Komamura et al. (2021) stated that some visitors even when they obtained pollen or nectar from flowers may not contribute as pollinators for some plant species. In other words, research on determining which flower visitors are pollinators requires more detailed observations at least like Komamura et al. (2021) did which were observing visiting frequency, counting the number of pollen grains per body surface, calculating fruit set, and investigating the mean number of seeds per fruit produced after a single visit of each visiting species. Another work also did by Boulter et al. (2006) on determining any animals as pollinators, among others by using trapping methods and video surveillance.

Yet another limitation of this study is the observation time of visiting insects during a day was limited and it maybe gives more results when the time of observation was extended. The reason for the selected time of observation done in this study was that this time was when most insects visited. Actually, there were also random observations during other times and the insects that appeared to visit were relatively the same and not too many in number or variety of species. The time stated here $(8-11 \mathrm{am})$ was the effective observation time which was routinely carried out during the full blooming period. 
Myrtaceae species do not have a specific pollination mechanism, but they magnetize a wide variety of flower visitors. Myrtaceae most common visitors are bees, nevertheless, several species of flies have also been reported to visit some Myrtaceae species (Gethika and Sabu 2017). Visitors insects of S. myrtifolium in this study is shown in Table 3 and Figure 2. This study recorded twelve insect species visiting $S$. myrtifolium during flowering season, three of them were bees, namely Apis cerana, Apis mellifera and Trigona sp., and two of them were flies, i.e. Chrysomya megacephala and Lucilia caesar.

Nevertheless, the flower-visiting insects of $S$. myrtifolium are mostly members of the order Lepidoptera (Table 3). Members of Lepidoptera consist of butterflies and moths. In this study, there were five species of butterflies (Euploea core, Hypolimnas bolina, Telicota colon, Eurema hecabe, Rapala pheretima) and two species of moths (Dysphania sagana, Amata trigonophora) found visiting flower of $S$. myrtifolium (Table 3, Figure 2). Hooks and Espindola (2020) believed that Lepidoptera was considered as important pollinator of various flowering plants, mainly in the wild as well as managed lands such as parks and yards.

Among 12 species, five of them (i.e. Apis cerana, Apis mellifera, Chrysomya megacephala, Euploea core and Eurema hecabe) were also noted visiting other Syzygium. Apis cerana was also noted visiting three other species i.e. S. caryophyllatum (Gethika and Sabu 2017), S. alternifolium (Raju et al. 2014), and S. occidentale (Kuriakose et al. 2018); Apis mellifera was also recorded coming to see S. tierneyanum (Hopper 1980), S. guinensee var. guineense (Djongwangwe et al. 2011), and S. sayeri (Boulter et al. 2005); Chrysomya megacephala was also observed visiting S. alternifolium (Raju et al. 2014); Euploea core was also recorded visiting S. caryophyllatum (Gethika and Sabu 2017) and S. alternifolium (Raju et al. 2014); whereas Eurema hecabe was also noted visiting $S$. caryophyllatum (Gethika and Sabu 2017).

This is influenced by several factors, including the shape of the flowers, color, aroma or the content of compounds such as nectar which attracts visitors, as mentioned by Boulter et al. (2006) that the type of flower display and interesting stimulant affects the type of visitors that may be appealed to perch on the flowers. Furthermore, they added that several research have shown that plant flowering patterns were generally an adaptive response to the availability of proper pollinators.

Finally, the results of this study are expected to fill the information gap for $S$. myrtifolium regarding the development of flowers and insect visitors, so as to be able to develop this species for other potentials (other than as ornamental plants) for example as a service provider for the environment (as a source of feed for pollinating animals, etc.), although the further better approaches in the characterization and identification of this plant and its insect visitors should be conducted.

\section{ACKNOWLEDGEMENTS}

The authors fully funded this research and there are no potential conflicts of interest.

\section{REFERENCES}

Agus NDP, Nurlalelih EE, Sitawati. 2015. Evaluasi Pemilihan Jenis dan Penataan Tanaman Median Jalan Kota Malang. Jurnal Produksi Tanaman 3(4): 269-277. [Indonesian]

Anggraini T. 2017. Antioxidant activity of Syzygium oleana. Pakistan Journal of Nutrition 16: 605-611. DOI: 10.3923/pjn.2017.605.611.

Astuti IP, Kusuma YWC, Yuswandi AY, Harto, Sunarti S. 2021. Fenologi perbungaan dan pembuahan serta perkecambahan biji Syzygium hirtum (Korth.) Merr. \& Perry L. M. di Kebun Raya Bogor. Buletin Kebun Raya 24 (1): 20-27. DOI: 10.14203/bkr.v24i1.717 [Indonesian]

Badou RB, Yedomonhan H, Adomou AC, Akoegninou A. 2017. Phénologie florale et production fruitière de Syzygium guineense (Willd.) DC. subsp. macrocarpum (Myrtaceae) en zone soudanoguinéenne au Bénin. International Journal Biological and Chemical Sciences 11 (5): 2466-2480. DOI: 10.4314/ijbcs.v11i5.41.

Badou RB, Yedomonhan H, Ewedje EEBK, Dassou GH, Adomou A, Tossou M, Akoegninou A. 2020. Floral morphology and pollination system of Syzygium guineense (Willd.) DC. subsp. macrocarpum (Engl.) F. White (Myrtaceae), a subspecies with high nectar production. S Afr J Bot 131: 462-467. DOI: 10.1016/j.sajb.2020.04.013

Bajpai A, Singh AK, Ravishankar H. 2012. Reproductive phenology, flower biology and pollination in jamun (Syzygium cuminii L.). Indian Journal of Horticulture 69 (3): 416-419.

Boulter SL, Kitching RL, Howlett BG, Goodall K. 2005. Any which way will do-the pollination biology of a northern Australian rainforest canopy tree (Syzygium sayeri; Myrtaceae). Botanical Journal of the Linnean Society 149 (1): 69-84. DOI: 10.1111/j.10958339.2005.00430.x

Boulter SL, Kitching RL, Zalucki JM, Goodall KL. 2006. Reproductive Biology and Pollination in Rainforest Trees: Techniques for a Community-level Approach. Cooperative Research Centre for Tropical Rainforest Ecology and Management. Rainforest CRC, Cairns, Australia.

Cho LH, Yoon J, An G. 2017. The control of flowering time by environmental factors. The Plant Journal 90 (4): 708-719. DOI: $10.1111 /$ tpj. 13461

Dewi SP, Rahayu A, Rochman N. 2015. Morfologi Bunga dan Viabilitas Serbuk Sari Berbagai Aksesi Pamelo (Citrus maxima (Burm.) Merr. Jurnal Agronida 1 (1): 37-45. DOI: 10.30997/jag.v1i1.130

Djonwangwe D, Fernand NTF, Messi J, Brückner D. 2011. Foraging and pollination activities of Apis mellifera adansonii Latreille (Apidae) on Syzygium guineense var. guineense (Myrtaceae) flowers at Ngaoundéré (Cameroon). Journal of Animal \& Plant Sciences 10 (3): 1325-1333.

Endress PK. 2010. Disentangling confusions in inflorescence morphology: Patterns and diversity of reproductive shoot ramification in angiosperms. Journal of Systematics and Evolution 48 (4): 225-239. DOI: 10.1111/j.1759-6831.2010.00087.x.

Efendi M, Puspitasari DN, Lestriani Y, Tatang. 2017. Pendataan Jenis Tumbuhan Koleksi Kebun Raya Cibodas untuk Materi Pelayanan Pendidikan Lingkungan. Al-Kauniyah: Journal of Biology 10 (2): 124-132. DOI: 10.15408/kauniyah.v10i2. 5209. [Indonesian]

Erwin J. 2005. Factors Affecting Flowering in Ornamental Plants. In: McDonald MB, Kwong FY (eds) Flower seeds: biology and technology. Cabi Publishing, UK.

Geethika K, Sabu M. 2017. Pollination biology of Syzygium caryophyllatum (L.) Alston (Myrtaceae). The International Journal of Plant Reproductive Biology 9 (1): 69-72. DOI 10.14787/ijprb.2017 9.1.69-72.

Haryati NA, Saleh C, Erwin. 2015. Uji Toksisitas dan Aktivitas Antibakteri Ekstrak Daun Merah Tanaman Pucuk Merah (Syzygium myrtifolium Walp.) Terhadap Bakteri Staphylococcus aureus dan Escherichia coli. Jurnal Kimia Mulawarman 13 (1): 35-40. [Indonesian] 
Hashifah FN, Lazuardi. 2016. Keanekaragaman Dan Kelimpahan Serangga Pengunjung Bunga Jambu Air Deli Hijau (Syzygium samarangense) Di Desa Kwala Begumit Stabat. Jurnal Biosains 2 (2): 67-71. [Indonesian]

Hasti S, Emrizal, Susilawati F. 2016. Antidiabetic Activities Test Of NHexana Ekstrak Of Syzygium myrtifolium Walp.

Leaves On White Mice Diabetes. Pharmacy 13 (02): 172-181.

Hooks CR, Espindola A. 2020. Moths, Butterflies, and Pollination. Marryland Agronomy News. http://blog.umd.edu/agronomynews/2020/06/05/moths-butterfliesand-pollination/

Hopper SD. 1980. Pollination of the Rain-Forest Tree Syzygium tierneyanum (Myrtaceae) at Kuranda, Northern Queensland. Aust J Bot 28 (2): 223-237. DOI: 10.1071/BT980022

Indriani L, Almasyhuri, Pratama AR. 2020. Aktivitas Gel Ekstrak Etanol Daun Pucuk Merah (Syzygium myrtifolium) Terhadap

Penyembuhan Luka Bakar Tikus Sprague-dawley. Fitofarmaka: Jurnal Ilmiah Farmasi 10 (2): 178-187. DOI: 10.33751/jf.v10i2.2233. [Indonesian]

Jain RK. 2011. Correlation study of flowering performance and flowering pattern with the yield in Linum usitatissimum L. African Journal of Plant Science 5 (3): 146-151. DOI: 10.5897/AJPS.9000054

Juwita R, Saleh C, Sitorus S. 2017. Antihyperuricemia Activity Test From Green Leaf Of Plant Red Bud (Syzygium myrtifolium Walp.) To Male Mice (Mus musculus). Jurnal Atomik 02 (1): 162-168.

Komamura R, Koyama K, Yamauchi T, Konno Y, Gu L. 2021. Pollination Contribution Differs among Insects Visiting Cardiocrinum

cordatum Flowers. Forests 12 (4): 452. DOI: 10.3390/f12040452

Kuriakose G, Sinu PA, Shivanna KR. 2018. Ant pollination of Syzygium occidentale, an endemic tree species of tropical rain forests of the Western Ghats, India. Arthropod-Plant Interactions 12: 647-655. DOI: 10.1007/s11829-018-9613-1.

Lack AJ, Kevan PG. 1984. On the Reproductive Biology of a Canopy Tree, Syzygium syzygioides (Myrtaceae), in a Rain Forest in Sulawesi, Indonesia. Biotropica 16 (1): 31-36. DOI: 10.2307/2387891

Lingga IS, Harahap U, Yuandani. 2018. Antimutagenic Effects Of Ethanol Extract Of Syzygium Myrtifolium Walp. in CyclophosphamideInduced Mice. Asian J Pharm Clin Res 11 (5): 210-213. DOI: 10.22159/ajpcr.2018.v11i6.24350.

Meyer DJL. 2005. Seed Development and Structure in Floral Crops. In McDonald MB, Kwong FY (eds) Flower seeds: biology and technology. Cabi Publishing, UK.

Mudiana D, Ariyanti EE 2010. Flower and fruit development of Syzygium pycnanthum Merr. \& L.M. Perry. Biodiversitas 11(3): 124-128. DOI https://doi.org/10.13057/biodiv/d110304.
Parnell J. 2003. Pollen of Syzygium (Myrtaceae) from SE Asia, especially Thailand. Blumea 48: 303-317.

POWO. 2019. Syzygium myrtifolium Walp. Plants of the World Online. Facilitated by the Royal Botanic Gardens, Kew. Published on the Internet; http://www.plantsoftheworldonline.org/ Retrieved 2 june 2021.

www.plantsoftheworldonline.org/taxon/urn:lsid:ipni.org:names:60445 221-2

Purnomo TAB, Yuliati L. 2020. High Antioxidant Activity of Pucuk Merah (Syzygium oleina) Leaf and Zinnia (Zinnia elegans) Flower Extracts. Indonesian Journal of Natural Pigments 02 (2): 54-58. DOI: 10.33479/ijnp.2020.02.02.54

Putri TD, Prasasti AG, Suliati, Idayanti T. 2020. Potensi Ekstrak Daun Pucuk Merah pada Tanaman Pucuk Merah (Syzygium myrtifolium

wlap) Sebagai Handsanitizer Alami in Irianto BG, Triwiyanto, Yulianto E et al. (eds). Prosiding Seminar Nasional Kesehatan. Politeknik Kesehatan Kementerian Kesehatan Surabaya, Surabaya 28 Nopember 2020. [Indonesian]

Raju AJS, Krishna JR, Chandra PH. 2014. Reproductive ecology of Syzygium alternifolium (Myrtaceae), an endemic and endangered tropical tree species in the southern Eastern Ghats of India. Journal of Threatened Taxa 6 (9): 6153-6171. DOI: 10.11609/JoTT.o3768.615371.

Santoni A, Darwis D, Syahri S. 2013. Isolation of Antosianin from Red Shoot (Syzygium campanulatum Korth.) as well as Antosianin Testing and Applications as Natural Dyes. In Dwi S, H Apkuanbo, S Saidi (eds). Prosiding Semirata. FMIPA Unila. Lampung, 10-12 Mei 2013. [Indonesian].

Sulistyo MAB. 2017. Aplikasi Ragam Metode Dan Konsentrasi ZPT (Alfatonik 13,46/9,6 L (B) Dalam Perbanyakan Tanaman Hias Pucuk Merah (Syzygium oleina Korth.). Primordia 13 (2): 65-79. [Indonesian]

Syahri S. 2012. Isolasi, Identifikasi, Dan Uji Antioksidan Senyawa Antosianin Dari Buah Pucuk Merah (Syzygium campanulatum Korth.) Serta Aplikasi Sebagai Pewarna Alami. [Thesis]. Universitas Andalas, Padang [Indonesian]

Syamsuwida D, Palupi ER, Siregar IZ, Indrawan A. 2012. Flower Initiation, Morphology, and Developmental Stages of FloweringFruitingof Mindi (Melia azedarach L.). Jurnal Manajemen Hutan Tropika (Journal of Tropical Forest Management) XVIII (1): 10-17. DOI: $10.7226 /$ jtfm.18.1.10.

Tarwotjo U, Hadi M, Rahadian R. 2019. Variasi Warna Dan Ketinggian Sticky Trap Dengan Atraktan Methyl Eugenol Sebagai Pengikat Serangga Polinator Dan Serangga Lainnya Pada Musim Bunga Pohon Jambu Air Merah Delima. Bioma 21 (1): 86-90. [Indonesian] 